\title{
Investigation of the factors that influence on the distribution of mollusc, Faunus sp. (Mollusca: Gastropoda: Thiaridae) along the Lunuwila Ela, Galle.
}

\author{
Udayantha $\mathrm{HMV}^{*}$ and Munasinghe $\mathrm{DHN}^{* 1}$ \\ ${ }^{1}$ Department of Zoology, University of Ruhuna, Matara \\ Correspondence:dhnm@zoo.ruh.ac.lk
}

\begin{abstract}
Factors that affect on the distribution of mollusc, Faunus species along the Lunuwila Ela, Galle was determined using ten environmental parameters. Four sites including 16 replicates were used and data were collected for six months. Among ten environmental parameters investigated, six of them are significantly different among sites. According to the results of regression analysis, none of the physiochemical parameters is responsible for the distribution of this species along this stream. However, it indicates, contents of the substrate make a favorable contribution on their distribution pattern which highest abundance of Faunas species recorded from the substrate with fine sand, silt and clay.
\end{abstract}

Keywords: Mollusca, Faunus sp., Lunuwila Ela: Galle, Distribution, Environmental parameters, substrate type

\section{Introduction}

The phylum mollusca is a large assemblage of animals having diverse shapes, sizes, habits and occupy in different habitats (Subba Rao, 1993). Based on their habitat preference, molluscs can be classified into aquatic and land communities. The biomass of the Mollusca is very important for ecosystems. In marine environments, molluscs may form the dominant group, especially in their larval stage. In freshwater environments biomass of molluscs is significant in some environments: for example, in temperate countries, lake bottoms may be covered with the small bivalves, which accounts for $80 \%$ of the biomass of benthic invertebrates (Seddon, 1986). As molluscs are primary consumers in aquatic ecosystems (Brown, 1991), they have been used as environmental indicators. Due to their economical and ecological importance, as well as sedentary life, molluscs have been assumed as an important organism in monitoring contaminants in different ecosystems (Feldstein et al. 2003). They are abundant, sedentary and easy to collect, which makes them ideal organisms in biomonitoring (Bresler et al. 2003) programs. Bivalve and gastropod molluscs are among the most useful organisms for environmental monitoring (Boening, 1999). Some molluscs are important (to the ecosystem) as parasite vectors. Freshwater molluscs, especially gastropods are important from the medical and veterinary public health point of view. About 100 species of freshwater gastropods are reported acting as intermediate hosts for the diagnostic trematode parasites and among Prosobranchs, members of the family Pilidae and Thiaridae were recorded as harbourers of larval trematodes (Subba Rao, 1993). 
However, molluscs are potentially at risk because of the impacts of human activities. Three major ways that fresh/brackish water mollusks have been impacted by human activities are introduction of exotic species, habitat loss or alteration and pollution of water. Sometimes, introduced (alien) species became invasive, causing biodiversity loss and inflicting major economic and/or ecological damage. The alteration of waterfront for recreation, housing, or commercial development can decrease the diversity of habitats available for molluscs. Industrialization including increasing traffic on the access roads leads to the increase of dust, which accumulates in the bottom of the aquatic habitats. Especially, accumulation of silt makes a major impact on the distribution of molluscs. Changing of other physicochemical parameters also directly or indirectly affect on the distribution of aquatic mollusks groups in the water bodies (Lardicci et al. 1997).

Lunuwila Ela is situated within the municipal council area of Galle. It starts from Walahanduwa area, which is approximately $16 \mathrm{Km}$ away from Galle town and ends in the Wakgalmodera estuary. The Lunuwila Ela consists of a mixture of saline and freshwater and this stream surrounds approximately $2 / 3$ of the well-known Holcim cement factory. The dust particles released from the factory may accumulate within this water body and leads to change the water quality and substrate type of it. It is prominent that siltation is one of the main ways that pollute this water body which makes a major impact on the distribution of the fauna in this stream. Different molluscan groups are available in this stream, which shows an irregular distributional pattern (Viraj and Munasinghe unpublished data). Among them gastropod, Faunus species received a considerable attention due to their patchy distribution. Therefore, the objective of this study was to investigate the environmental parameters that affect on the distribution of mollusc, Faunus sp. along Lunuwila Ela, Galle.

\section{Methodology}

The experiment was conducted from January to June 2007 and data were collected once a month. Four sites were selected along the Lunuwila Ela from down to the up-stream direction, and each covered approximately $15 \mathrm{~m}$ in length. Distance between two sites was approximately $250 \mathrm{~m}$. Each site included four replicates and they were selected from both sides of the stream. The distance between each two replicates was approximately $10 \mathrm{~m}$. Each replicate was covered $1 \mathrm{~m}^{2}$ area. Sites were labeled as 1, 2, 3, and 4 and replicates were labeled as $1 \mathrm{a}, 1 \mathrm{~b}, 1 \mathrm{c}, 1 \mathrm{~d}$ etc.

After placing quadrates all visible Faunas shells were counted. Mud and sand particles were removed (upper $5 \mathrm{~cm}$ layer) and rocks and vegetation were thoroughly inspected for mollusks. Sampling was conducted over a period of 6 months. Physical and chemical parameters were determined according to the established standard methods (Hadrian, 1985). Temperature was measured at the site and water samples were taken from each replicate for the analysis of water quality parameters. Dissolve Oxygen (DO), Biological Oxygen Demand (BOD), Chemical Oxygen Demand (COD), Alkalinity, Suspended Solids (SS), Total Dissolved Solids (TDS) and Salinity were measured at the laboratory. Finally, a sample of the substrate from each replicate was mixed with water and allowed to separate into layers in a measuring cylinder and contents were recorded. 
There was no significant variation determined within temporal data that measured for different parameters. Therefore, for a particular replicate, obtained temporal data for each parameter were added up to get a mean value. Finally, a single mean value for each parameter was calculated for each site using replicate data. Using multiple comparison option of ANOVA, variations of parameters among sites were compared. A regression analysis was carried out to find out the relationship among water quality parameters and abundance of individuals of the Genus Faunus using SPSS version 10 statistical packages.

\section{Objectives}

Results of the ANOVA and regression analysis were given in Table 1 and 2 . According to the results, COD, BOD, DO, Salinity, Temperature, Hardness and the abundance of the Genus Faunus were significantly different among four sites. There is no considerable regression between physicochemical parameters and the abundance of Faunus sp was resulted for four sites. Shells for Faunas $s p$ were not recorded from the site 4 . Number of shells for Faunus sp. that recorded for each replicate is given in the Table 3. Even within one site, contents of the substrate were highly variable among replicates. Substrate with coarse sand, fine sand, silts and clay is the common type for four sites. The highest abundance of Faunus sp can be seen in the Site $02 \mathrm{c}$ which the substrate consisted with fine sand, silt and clay.

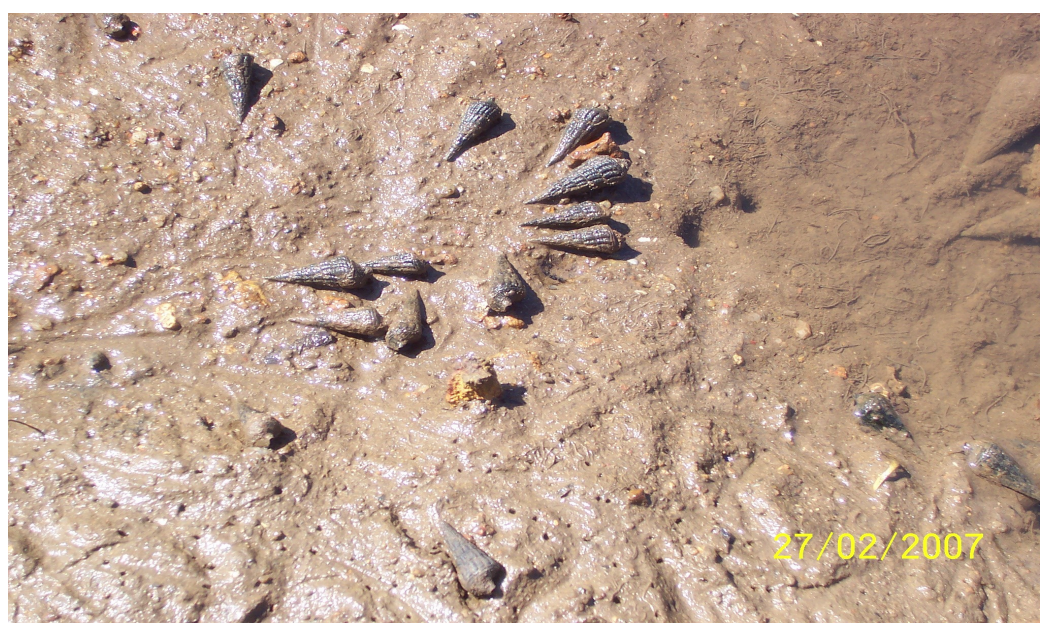

Figure 1: Substrate of the Faunus species

Table 1: Mean values, standard deviation and significance levels for different parameters of the four sites. 


\begin{tabular}{|c|c|c|c|c|c|}
\hline \multirow{2}{*}{$\begin{array}{l}\text { Paramete } \\
r\end{array}$} & \multicolumn{4}{|c|}{ Mean Value $\pm S D$} & \multirow{2}{*}{$\begin{array}{l}\text { Sig. } \\
\text { value }\end{array}$} \\
\hline & Site 1 & Site 2 & Site 3 & Site 4 & \\
\hline $\begin{array}{l}\mathrm{COD} / \mathrm{mg} \\
L^{-1}\end{array}$ & $\begin{array}{l}0.0254 \pm \\
0.0030\end{array}$ & $\begin{array}{l}0.0317 \pm \\
0.0063\end{array}$ & $\begin{array}{l}0.0254 \pm \\
0.0046\end{array}$ & $\begin{array}{l}0.0303 \pm \\
0.0061\end{array}$ & $0.000 *$ \\
\hline $\begin{array}{l}B O D / m g \\
L^{-1}\end{array}$ & $\begin{array}{l}3.1668 \pm \\
1.0660\end{array}$ & $\begin{array}{l}2.0631 \pm \\
0.9603\end{array}$ & $\begin{array}{l}1.6424 \pm \\
1.3079\end{array}$ & $\begin{array}{l}1.5102 \quad \pm \\
1.1448\end{array}$ & $0.000 *$ \\
\hline${ }_{1}^{\mathrm{DO} / m g L^{-}}$ & $\begin{array}{l}4.5143 \pm \\
1.1672\end{array}$ & $\begin{array}{l}9.2928 \pm \\
1.9744\end{array}$ & $\begin{array}{l}6.1769 \pm \\
1.9240\end{array}$ & $\begin{array}{l}6.2256 \pm \\
2.9162\end{array}$ & $0.022 *$ \\
\hline$S A L / p p t$ & $\begin{array}{l}25.6353 \pm \\
10.0611\end{array}$ & $\begin{array}{l}19.8812 \pm \\
9.8910\end{array}$ & $\begin{array}{l}17.3149 \pm \\
10.6489\end{array}$ & $\begin{array}{l}14.4282 \\
\pm 11.4830\end{array}$ & $0.010^{*}$ \\
\hline $\begin{array}{l}A L K / m \\
m o l L^{-1}\end{array}$ & $\begin{array}{l}0.0102 \pm \\
0.0091\end{array}$ & $\begin{array}{l}0.0079 \pm \\
0.0068\end{array}$ & $\begin{array}{l}0.0069 \pm \\
0.0057\end{array}$ & $\begin{array}{l}0.0055 \pm \\
0.0053\end{array}$ & 0.195 \\
\hline $\begin{array}{l}T E M P / \\
{ }^{\circ} C\end{array}$ & $\begin{array}{l}31.0 \quad \pm \\
2.97\end{array}$ & $\begin{array}{l}33.0 \quad \pm \\
3.44\end{array}$ & $\begin{array}{l}33.8 \quad \pm \\
2.53\end{array}$ & $\begin{array}{l}32.0 \quad \pm \\
2.96\end{array}$ & $0.018^{*}$ \\
\hline$H A R D$ & $\begin{array}{l}0.0389 \pm \\
0.0153\end{array}$ & $\begin{array}{l}0.0298 \pm \\
0.0166\end{array}$ & $\begin{array}{l}0.0217 \\
0.0178\end{array}$ & $\begin{array}{l}0.0272 \pm \\
0.0162\end{array}$ & $0.001 *$ \\
\hline$\underset{1}{S S} / \mathrm{mgml}^{-}$ & $\begin{array}{l}0.0350 \\
\pm 0.0191\end{array}$ & $\begin{array}{l}0.0429 \pm \\
0.0260\end{array}$ & $\begin{array}{l}0.0455 \pm \\
0.0351\end{array}$ & $\begin{array}{l}0.0385 \pm \\
0.0270\end{array}$ & 0.632 \\
\hline $\begin{array}{l}T D S / m g \\
m l^{-1}\end{array}$ & $\begin{array}{l}0.0214 \pm \\
0.0116\end{array}$ & $\begin{array}{l}0.0172 \pm \\
0.0139\end{array}$ & $\begin{array}{l}.00133 \\
\pm 0.0120\end{array}$ & $\begin{array}{l}0.0130 \pm \\
0.0123\end{array}$ & 0.133 \\
\hline $\begin{array}{l}\text { Abundan } \\
\text { ce of } \\
\text { Faunus } \\
\text { sp. }\end{array}$ & $\begin{array}{l}25.45 \quad \pm \\
6.15\end{array}$ & $\begin{array}{l}147.15 \pm \\
95.07\end{array}$ & $\begin{array}{l}5.70 \quad \pm \\
4.46\end{array}$ & $\begin{array}{l}0.00 \\
0.00\end{array}$ & $0.000 *$ \\
\hline
\end{tabular}

(Significant level $<0.05$ )

(* indicate the parameters, which are significantly different among four sites.) 
Table 2: Results of the regression analysis between physicochemical parameters and the abundance of Faunus species

\begin{tabular}{|l|l|l|l|l|}
\hline Parameter & $\begin{array}{l}R^{2} \text { value } \\
\text { for site 01 }\end{array}$ & $\begin{array}{l}R^{2} \text { value for } \\
\text { site 02 }\end{array}$ & $\begin{array}{l}R^{2} \text { value for } \\
\text { site 03 }\end{array}$ & $\begin{array}{l}R^{2} \text { value } \\
\text { for site 04 }\end{array}$ \\
\hline$C O D / m g L^{-1}$ & 0.039 & 0.002 & 0.063 & - \\
\hline$B O D / m g L^{-1}$ & 0.003 & 0.166 & 0.053 & - \\
\hline$D O / m g L^{-1}$ & 0.019 & 0.167 & 0.007 & - \\
\hline$S A L / p p t$ & 0.022 & 0.000 & 0.109 & - \\
\hline $\begin{array}{l}A L K / \\
m o l L^{-1}\end{array}$ & 0.035 & 0.005 & 0.024 & - \\
\hline$T E M P /{ }^{\circ} C$ & 0.039 & 0.242 & 0.012 & - \\
\hline$H A R D$ & 0.046 & 0.004 & 0.147 & - \\
\hline$S S / m g l^{-1}$ & 0.070 & 0.009 & 0.077 & - \\
\hline $\begin{array}{l}T D S / m g ~ m l \\
1\end{array}$ & 0.006 & 0.016 & 0.143 & - \\
\hline
\end{tabular}

Table 3: Contents of substrate and the recorded number of Faunus sp for each site

\begin{tabular}{|l|l|l|l|}
\hline Site & Replicates & Content of substrate & $\begin{array}{l}\text { Recorded } \\
\text { number }\end{array}$ \\
\hline \multirow{3}{*}{01} & $a$ & Silt, Clay & 165 \\
\cline { 2 - 5 } & $b$ & Fine sand, silt, clay & 416 \\
\cline { 2 - 4 } & c & Fine sand, silt, clay & 28 \\
\cline { 2 - 4 } & d & Coarse sand, Fine sand, silt, clay & 34 \\
\hline
\end{tabular}




\begin{tabular}{|c|c|c|c|}
\hline \multirow{4}{*}{02} & $a$ & Coarse sand, Fine sand, silt, clay & 90 \\
\hline & $b$ & $\begin{array}{l}\text { Stone, Gravel, Coarse sand, Fine } \\
\text { sand, silt, clay }\end{array}$ & 306 \\
\hline & $c$ & Fine sand, silt, clay & 2055 \\
\hline & $d$ & $\begin{array}{l}\text { Gravel, Coarse sand, Fine sand, } \\
\text { silt, clay }\end{array}$ & 69 \\
\hline \multirow{4}{*}{03} & $a$ & Coarse sand, Fine sand, silt, clay & 25 \\
\hline & $b$ & Coarse sand, Fine sand, silt, clay & 22 \\
\hline & $c$ & Coarse sand, Fine sand, silt, clay & 34 \\
\hline & $d$ & Coarse sand, Fine sand, silt, clay & 19 \\
\hline \multirow{4}{*}{04} & $a$ & Coarse sand, Fine sand, silt, clay & 0 \\
\hline & $b$ & Coarse sand, Fine sand, silt, clay & 0 \\
\hline & $c$ & Coarse sand, Fine sand, silt, clay & 0 \\
\hline & $d$ & $\begin{array}{l}\text { Gravel, Coarse sand, Fine sand, } \\
\text { silt, clay }\end{array}$ & 0 \\
\hline
\end{tabular}

\section{Discussion}

The distribution and dynamics of molluscan communities living in estuary ecosystems are strongly influenced by fluctuations of the physicochemical factors that induced by the mixing of freshwater and sea inflows. According to the results, few parameters varied along the stream. Among ten parameters evaluated, five of them were (BOD, Salinity, Alkalinity, Hardness, and TDS) gradually increased along the stream from head to the mouth. Other four parameters (COD, DO, SS, temperature) did not show any considerable variation. It could be assumed, that due to the mixing of saline and freshwater, the ionic strength of the water becomes increased towards to the mouth thus increased the salinity, alkalinity and hardness. Towards to the mouth, the flow rate gradually decreases which promote the accumulation of organic matter and increase the total amount of suspended particles as well as the BOD values. According to the current study, six parameters (COD, BOD, DO, Salinity, Temperature, Hardness and Faunus sp) showed significant difference among sites. However, according to the results of multiple comparisons of ANOVA (Turkey HSD), the 
degrees of variation among sites were varied for measured parameters Appendix 1). According to the regression analysis a considerable relationship between distribution of Faunus sp. and the physicochemical parameters could not be determined (Table 2).

The substrate type was varied among the four sites (Table 3). The common substrate type consisted with coarse sand, find sand, silt and clay. The highest number of individuals of genus Faunus was recorded from the site 2 and none were recorded from the site 4. Among studied parameters, six of them (COD, BOD, DO, Salinity, Temperature and Hardness) were significantly different between site two and others (Appendix 1). However this experimental area, especially site 1-3 are more vulnerable to accumulation of very fine particles that are released by the cement factory. Slow flow rate of site 2 also caused high accumulation of silt materials on the substrate. The substrate that showed highest abundance of individuals (replicate 2c) consisted with fine sand, silt and clay. These observations conclude that substrate builds up with fine materials leads to accumulation of individuals in high numbers. Therefore, it can be assumed substrate is one of the major factors that influence on the distribution of Faunus $s p$ along this stream. Further it can be concluded that this species could be use as an indicator for the presence of substrate type, which consist with fine particles.

\section{Acknowledgements}

We thank N.M.B.G. Nishshanka, I.D.K.L. Fernando and C.H. Priyantha for giving help in field studies. This research was conducted as a partial fulfillment of B.Sc. special degree program, which was supported by the Department of Zoology, University of Ruhuna.

\section{References}

Boening DW. 1999. An evaluation of bivalves as bio-monitors of heavy metals pollution in marine waters. Environmental Monitoring and Assessment 55, 459-470.

Bresler V. 2003. Marine mollusc in environmental monitoring. II. Experimental exposure to selected pollutants. Helgoland Marine Research 57, 206-211.

Brown D S. 1991. Freshwater Snails of Africa and their Medical Importance. Taylor \& Francis, Ltd., London. 487 pp.

Feldstein T. 2003. Marine mollusc in environmental monitoring. III. Trace metals and organic pollutants in animal tissue and sediments. Helgoland Marine Research 57, 212-219.

Hadrian, P. S., Malcolm C. M. B., Lindsay, G. R \& Michael, J. P. (1985). Chemical and Biological methods of water analysis for Aqua culturists. Sterling printed, Great Britain.

Lardicci C, Rossi F, \& Castillo A. 1997. Analysis of macrozoobenthic community structure after severe dystrophic crises in a Mediterranean coastal lagoon.

Seddon M. 1886. Molluscan Biodiversity and the Impact of Large Dams National Museum and Galleries of Wales, UK Co-chair IUCN Mollusc Specialist Group 
Subba Rao NV. 1993. Freshwater Molluscs of India. In: Roa K.S. (Ed.). Recent Advances in Freshwater Biology. New Delhi. Anmol Publication. Volume 2. pp. 187-202.

\section{Appendix}

Appendix 01: Multiple comparisons (Turkey HSD) of physicochemical parameters among four sites.

\section{Appendix 01 (i): Multiple comparisons Chemical Oxygen Demand (COD) levels among sites}

\begin{tabular}{|l|l|l|l|l|}
\hline Site & 1 & 2 & 3 & 4 \\
\hline 1 & & $* *$ & $* *$ & $* *$ \\
\hline 2 & $* *$ & & -- & -- \\
\hline 3 & $* *$ & -- & & -- \\
\hline 4 & $* *$ & -- & -- & \\
\hline
\end{tabular}

(*indicates the COD which significantly different among four sites)

Appendix 01(ii): Multiple comparisons of Biological Oxygen Demand (BOD) levels among sites

\begin{tabular}{|l|l|l|l|l|}
\hline Site & 1 & 2 & 3 & 4 \\
\hline 1 & & $* *$ & $* *$ & $* *$ \\
\hline 2 & $* *$ & & -- & -- \\
\hline 3 & $* *$ & -- & & - \\
\hline 4 & $* *$ & -- & -- & \\
\hline
\end{tabular}

(*indicates the BOD which significantly different among four sites)

Appendix 01 (iii): Multiple comparisons Dissolve Oxygen (DO) levels among sites 


\begin{tabular}{|l|l|l|l|l|}
\hline Site & 1 & 2 & 3 & 4 \\
\hline 1 & & $* *$ & -- & -- \\
\hline 2 & $* *$ & & -- & -- \\
\hline 3 & -- & -- & & -- \\
\hline 4 & -- & -- & -- & \\
\hline
\end{tabular}

(*indicates the DO which significantly different among four sites)

Appendix 01 (iv): Multiple comparisons of Salinity (SAL) levels among sites

\begin{tabular}{|l|l|l|l|l|}
\hline Site & 1 & 2 & 3 & 4 \\
\hline 1 & & -- & -- & $* *$ \\
\hline 2 & -- & & -- & -- \\
\hline 3 & -- & -- & & -- \\
\hline 4 & $* *$ & -- & -- & \\
\hline
\end{tabular}

(*indicates the SAL which significantly different among four sites)

Appendix 01 (v): Multiple comparisons of Temperature (TEMP) among sites

\begin{tabular}{|l|l|l|l|l|}
\hline Site & 1 & 2 & 3 & 4 \\
\hline 1 & & $* *$ & -- & -- \\
\hline 2 & $* *$ & & -- & -- \\
\hline 3 & -- & -- & & -- \\
\hline
\end{tabular}




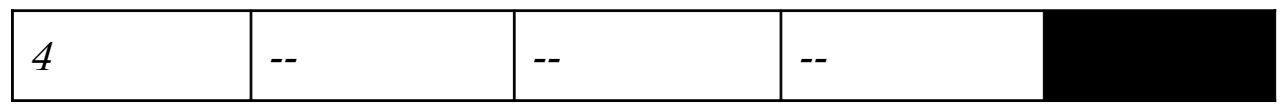

(*indicates the TEMP which significantly different among four sites)

Appendix 08 (vi): Multiple comparisons of Hardness (HARD) among sites

\begin{tabular}{|l|l|l|l|l|}
\hline Site & 1 & 2 & 3 & 4 \\
\hline 1 & & -- & $* *$ & $* *$ \\
\hline 2 & -- & & -- & -- \\
\hline 3 & $* *$ & -- & & -- \\
\hline 4 & $* *$ & -- & -- & \\
\hline
\end{tabular}

(*indicates the HARD which significantly different among four sites)

\section{Appendix 08 (vii): Multiple comparaisons of abundance of Faunus among sites}

\begin{tabular}{|l|l|l|l|l|}
\hline Site & 1 & 2 & 3 & 4 \\
\hline 1 & & $* *$ & -- & -- \\
\hline 2 & $* *$ & & $* *$ & $* *$ \\
\hline 3 & -- & $* *$ & & -- \\
\hline 4 & -- & $* *$ & -- & \\
\hline
\end{tabular}

(*indicates the abundance of Faunus sp which significantly different among four sites) 